\title{
First record of Cheilomenes sexmaculata (Fabricius, 1781) (Coleoptera, Coccinellidae) from Colombia
}

\author{
José Ramírez, ${ }^{1}$ Guillermo González, ${ }^{2}$ Yuly Sánchez ${ }^{3}$ \\ 1 Pontificia Universidad Javeriana, Departamento de Biología, Laboratorio de Entomología, Bogotá, Colombia. 2 La Reina, Santiago, Chile. \\ 3 Universidad del Atlántico, Departamento de Biología Atlántico, Colombia. \\ Corresponding author: José Ramírez, areisus@gmail.com
}

\begin{abstract}
The ladybird Cheilomenes sexmaculata is reported for the first time from Colombia. Previously, this species was recorded in Asia and Australia, then introduced to South America and reported from countries such as Chile, Ecuador, Perú, and Venezuela, where it is used for biological control.
\end{abstract}

\section{Key words}

Ladybird beetle; citrus crops; range extension; Neotropics.

Academic editor: Bruno Clarkson | Received 23 March 2017 | Accepted 28 August 2017 | Published 5 January 2018

Citation: Ramírez J, González G, Sánchez Y (2017) First record of Cheilomenes sexmaculata (Fabricius, 1781) (Coleoptera: Coccinellidae) from Colombia. Check List 14 (1): 77-80. https://doi.org/10.15560/14.1.77

\section{Introduction}

Cheilomenes sexmaculata (Fabricius, 1781) is a coccinellid species of the tribe Coccinellini (Slipinski 2007). It was originally described from Asia (India, Bangladesh, Pakistan, Sri Lanka, Bhuran, Myanmar, Malaysia, Indonesia, Vietnam, China, and Japan), but it has also been reported in Australia (Poorani 2002). More recently, it has been reported from countries in South America such as Chile, Ecuador, Perú, and Venezuela (González 2008, Angulo et al. 2011, Cornejo and González 2015, González 2016).

Cheilomenes sexmaculata is a species that has been studied for its potential as a pest control agent in biological control due to its eating habits, being a natural predator of aphid pest species such as Aphis caccivora Kock, 1854, A. gossypii Glover 1887 and Lipaphis erysimi (Kaltenbach, 1843), which are problematic for a variety of crops (Agarwala and Yasuda 2000, Agarwala et al 2001, Omkar and Bind 2004, Tank and Korat 2007, Joshi and Sharma 2008, Angulo et al. 2011). Moreover, it has been reported feeding on foliar nectaries of Talipariti pernambucense (Arruda) Fryxell in mangroves from Ecuador, taking advantage of the sugary substrates of nectaries as a food resource (Cornejo and Gonzalez 2015).

\section{Methods}

On 28 April 2016, 9 specimens of C. sexmaculata were identified from different citrus plantations across the Caribbean coast of Colombia. Two of the specimens were from an orange plantation Citrus sinesis (L) Osbeck located in the Luruaco municipality in the Colombian department of Atlántico $\left(10^{\circ} 59^{\prime} 99^{\prime \prime} \mathrm{N}, 075^{\circ} 18^{\prime} 21^{\prime \prime} \mathrm{W}\right)$ at 31 $\mathrm{m}$ above sea level (asl). The other 7 specimens were from a lemon plantation Citrus $\times$ limon (L) Burm located in the Santo Tomas municipality $\left(10^{\circ} 732^{\prime} 40^{\prime \prime} \mathrm{N}, 074^{\circ} 81^{\prime} 28^{\prime \prime} \mathrm{W}\right)$ 


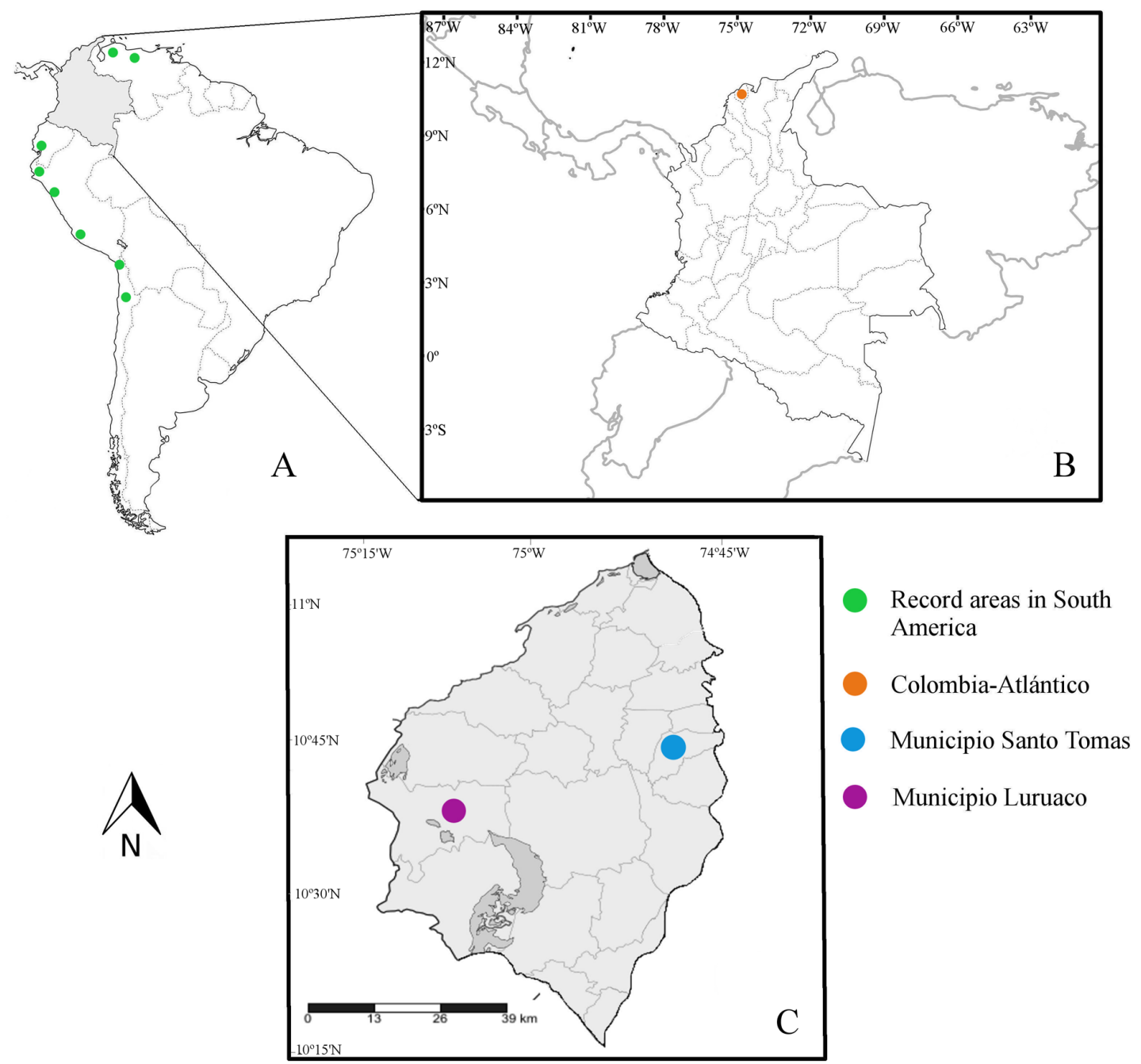

Figure 1. Distribution map of Cheilomenes sexmaculata in Neotropical region: A. Record areas in South America. B. New record from Colombia. C. Geographic distribution in Atlántico department.

at $48 \mathrm{~m}$ asl (Fig. 1). They were also seen feeding on other citrus crops. The species has been observed predating upon Capulinia linarosae Kondo and Gullan (2016) in plantations of guava Psidium guajava L.

Species identification was done using a stereomicroscope Leica S8 APO coupled to a digital camera Leica MC170 HD. Images were captured using the software Leica Aplication Suite (LAS) Version 4.6 and the construction of the final images were done with the software Zerene Stacker Version 1.0. Posterior treatment was performed in Gnu Image Manipulation Program (GIMP) version 2.8 .

The specimens were deposited in the entomological collection of the Museo Javierano de Historia Natural "Lorenzo Uribe, S.J." of the Pontificia Universidad Javeriana from Colombia, catalog numbers MPUJ_ENT 0013112 to MPUJ_ENT 0013120.

\section{Results}

New records. Colombia, Atlántico, Luruaco $\left(10^{\circ} 59^{\prime}\right.$ 99" N, 075¹8'21" W), Yuly Sánchez, 28 April 2016, MPUJ_ENT 0013112 to MPUJ_ENT 0013120, 2 specimens. Colombia, Atlántico, Santo Tomás (10732'40" N,
07481'28" W), Yuly Sánchez, 28 April 2016, MPUJ ENT 0013112 to MPUJ_ENT 0013120, 7 specimens.

Identification. Taxonomic identification was based on the original description of the species (Mulsant 1850) and a recent diagnosis update (Slipinski 2007). Cheilomenes sexmaculata can be recognized by the following combination of characteristics: Anterior clypeal border arcuate; antenna 11-segmented; distinctly short, asymmetrical scape and compact 3-segmented club; terminal maxillary palpomere securiforme; prothoracic hypomeron without fovea near anterior angles; intercoxal process with a pair of distinct carinae extending anteriorly; anterior margin of mesostern weakly emarginate medially; elytral margin narrow, raised margins but without thickened border; epipleuron weakly foveate; abdominal postcoxal line not recurved and incomplete laterally, with oblique additional line; penis consists of single sclerite, ovopositor with coxites club-handle type; and ejaculatory duct very long and complex (Slipinski 2007).

The patterns of elytra coloration are highly variable, according Vijay et al (2016); combinations can be presented, such as: elytral yellow, pink, orange, and red, with 3 zig-zags black; elytra with black suture line 

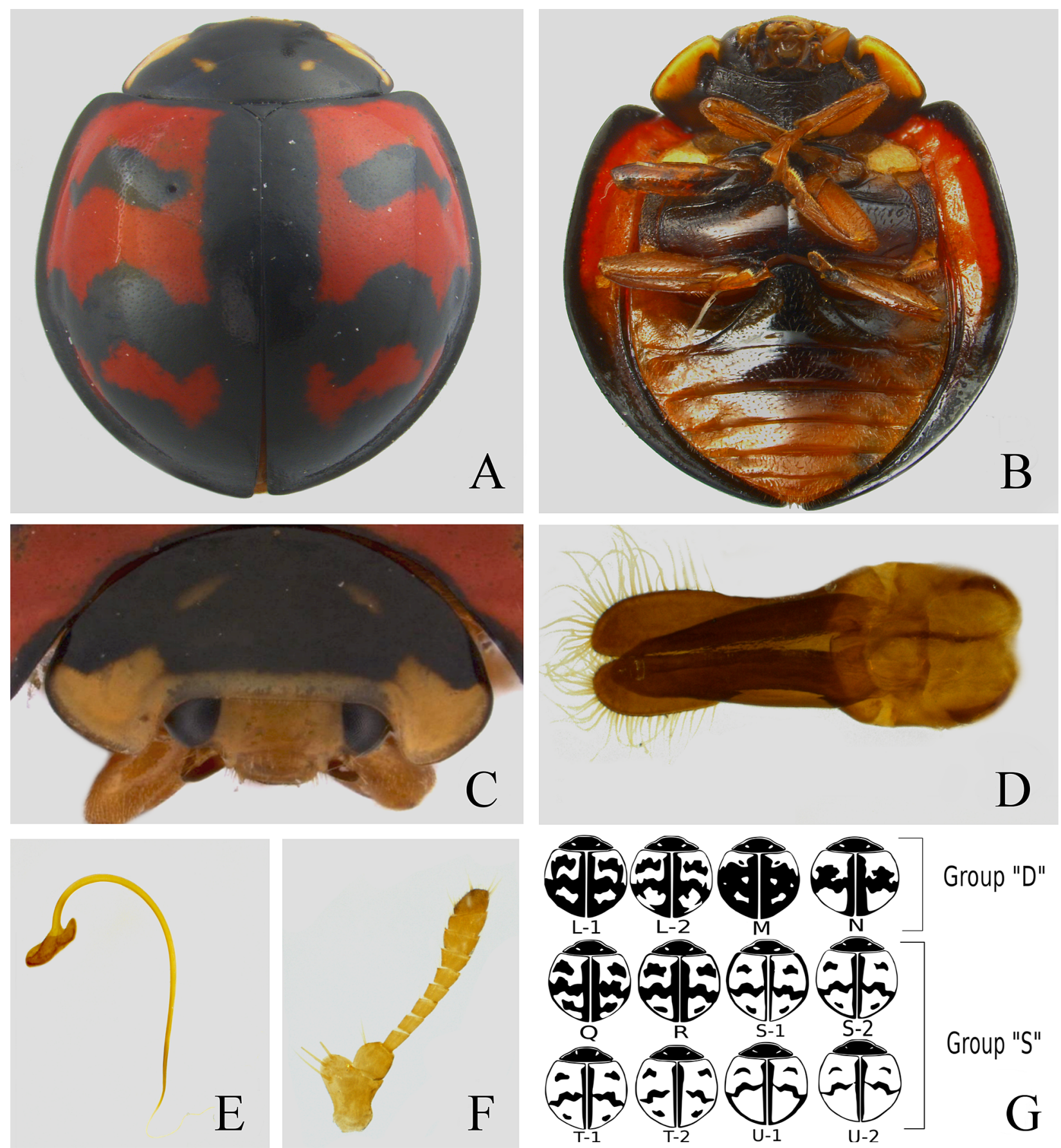

Figure 2. Cheilomenes sexmaculata. A. Dorsal view. B. Ventral view. C. Front view. D. Male genitalia: phallobase, dorsal view. E. Male genitalia: Sipho (penis). F. Antenna, asymmetrical scape and compact 3-segmented club. G. Phenotypes of group " $\mathrm{D}$ " and "S" modified from Kawakami et al. (2013).

without any spot; elytra with any spot; elytral completely black except margins; black elytra with 2 brownish spots on posterior side; and black elytra with yellow zig-zag band in the centre.

\section{Discussion}

According to Sasaji and Akamatsu (1979) and Matsuka et al. (1985) C. sexmaculata has 23 elytral phenotypes based on color, which have been classified into distinct phenotypic groups: quadriplagiata, unifasciata, diversijunata, and sexmaculata form. The specimens observed belong to the diversijunata (phenotype L) and sexmaculata (phenotype Q) form, which are distributed in low latitudes and are characterized by presenting a yellow head, black pronotum with small yellow spots in the anterior and discal region, and a reddish-orange coloration in the elytra with bands and black spots (Fig. 2). This study provides new evidence for the ecology and distribution of the species, being reported $C$. sexmaculata for the first time in Colombia.

\section{Acknowledgements}

We are grateful to Camilo Lopez-Aguirre and Edgard Palacio for their comments and suggestions on earlier 
versions of the manuscript. The authors also thank the anonymous reviewers.

\section{Authors' Contributions}

YS collected the specimens, JR and GG wrote the text, and JR took the photographs and wrote the text.

\section{References}

Agarwala B, Yasuda H (2000) Competitive ability of ladybird predators of aphids: a review of Cheilomenes sexmaculata (FABR.) (Coleoptera: Coccinellidae) with a worldwide checklists of preys. Journal of Aphidology 14: 1-20.

Agarwala B, Bardhanroy P, Yasuda H, Takizawa T (2001) Prey consumption and oviposition of the aphidophagous predator Menochilus sexmaculatus (Coleoptera: Coccinellidae) in relation to prey density and adult size. Environmental Entomology 30 (6): 1182-1187. https://doi.org/10.1603/0046-225X-30.6.1182

Angulo, J, Arcaya E, González R (2011) Aspectos biólogicos de Menochilus sexmaculatus (F.) (Coleoptera: Coccinellidae) alimentado con Aphis craccivora Koch (Hemiptera: Aphidae). Boletín de Centro de Investigaciones Biológicas 45 (4): 423-431.

Cornejo X, González G (2015) Contribución al conocimiento de la fauna entomológica de los manglares: Olla roatanensis Vandenberg y Cheilomenes sexmaculata Fabricius, dos nuevos registros de Coleoptera: Coccinellidae para Ecuador y Perú. Revista Científica de Ciencias Naturales y Ambientales (Ecuador) 8 (2): 76-80.

Fryxell (2001) Contributions from the University of Michigan Herbarium 23: 262.

Glover T (1877) Homoptera. In: Report of the Entomologist and Curator of the Museum. Report of the Commissioner of Agriculture 1876: $17-46$

González G (2008) Lista y distribución geográfica de especies de Coccinellidae (Insecta: Coleoptera) presentes en Chile. Boletín de Museo Nacional de Historia Natural, Chile 57: 77-107.

González G (2016) Los Coccinellidae de Colombia. http:/www. coccinellidae.cl/paginasWebCol/Paginas/InicioCol.php. Accessed on: 2017-10-23.

Joshi P, Sharma P (2008) First records of coccinellid beetles (Coccinellidae) from the Haridwar (Uttarakhand), India. The Natural
History Journal of Chulalongkorn University 8 (2): 157-167.

Kaltenbach.(1843) Monographie der Familien der Pflanzenläuse (Phytophthires), P. Fagot, Aachen, 222 pp.

Kawakami Y, Yamazaki K, Ohashi K (2013) Geographical variations of elytral color polymorphism in Cheilomenes sexmaculata (Fabricius) (Coleoptera: Coccinellidae). Entomological Science 16: 235-242. https://doi.org/10.1111/ens.12005

Koch CL (1854) Die Pflanzenläuse Aphiden getreu nach dem Leben abgebildet und beschrieben. JL Lotzbeck, Nürnberg 4:101-134.

Kondo T, Gullan PJ, Cook LG (2016) A review of the genus Capulinia Signoret (Hemiptera: Coccoidea: Eriococcidae) with description of two new species. Zootaxa 4111 (4): 471-491. https://doi.org/ 10.11646/zootaxa.4111.4.7

Matsuka M, Sato Y, Niijima K (1985) The heredity of elytral color polymorphism in Cheilomenes sexmaculata (Coleoptera: Coccinellidae). Bulletin of the Faculty of Agriculture Tamagawa University 25: 91-97.

Mulsant E (1850) Species de Coleóptères Trimères Sécuripalpes. Annales des Sciences Physiques et Naturelles, d'Agriculture et d'Industrie, Lyon (Série 2): 1-1104.

Omkar, Bind RB (2004) Prey quality dependent growth, development and reproduction of a biocontrol agent, Cheilomenes sexmaculata (Fabricius) (Coleoptera: Coccinellidae). Biocontrol Science and Technology 14:665-673.https://doi.org/10.1080/091583150410001 682359

Poorani J (2002) An annotated checklist of the Coccinellidae (Coleoptera) (excluding Epilachninae) of the Indian subregion. Oriental Insects 36: 307-383. https://doi.org/10.1080/00305316.2002.10417335

Sasaji H, Akamatsu M (1979) Reproductive continuity and genetic relationships in the forms of the Genus Menochilus (Coleoptera: Coccinellidae). Memoirs of the Faculty of Liberal Arts, University of Fukui. Series II, Natural Science 29: 1-18.

Slipinski A (2007) Australian Ladybird Beetles (Coleoptera: Coccinellidae) their Biology and Classification. Australian Biological Resources Study, Canberra, 306 pp.

Tank BD, Korat DM (2007) Biology of ladybird beetle, Cheilomenes sexmaculata (Fab.) in middle Gujarat conditions. Karnataka Journal of Agricultural Sciences 20 (3): 634-636.

Vijay S, Vivek G, Suman D, Santosh H Vinay M (2016) Polymorphism of Cheilomenes sexmaculata (Fabricius) (Coleoptera: Coccinellidae) in Haryana, India. Journal of Entomology and Zoology Studies 4(5): 548-551. 